\title{
Synthesis of L-Ascorbic Acid Derivative Including 3-Aminopropane Phosphoric Acid as a Novel Whitening Agent
}

\author{
Hak Hee Kang and Seong-Geun $\mathrm{Oh}^{*}$ \\ Department of Chemical Engineering, College of Engineering, Hanvang Universin, Seoul 133-791, Korea \\ Received Mav 12, 2003
}

\begin{abstract}
A stable derivative of $\mathrm{L}$-ascorbic acid. 2-O-[(3-aminopropyl)phosphinooxy]-L-ascorbic acid (LAAP). was synthesized in moderate yield and its chemical stability and effects on melanin synthesis were investigated. LAscorbic acid was decomposed completely within about 1 hour. while $93 \%$ of LAAP remained even after 10 days. Treatment of L-ascorbic acid and LAAP decreased melanin content in nornal human melanocytes to $33.8 \%$ and $49.1 \%$ of control at $2 \mathrm{mM}$, respectively. Considering chenucal instability of $\mathrm{L}$-ascorbic acid, LAAP is a much better whitening agent.
\end{abstract}

Key Words : 2-O-[(3-Aminopropỵl)phosphinooxy]-L-ascorbic acid (LAAP), Whitening agent

\section{Introduction}

Since its discovery in the late 1920 s. $^{1}$ probably no other chemical has ever been as celebrated as L-ascorbic acid. The beneficial effect of L-ascorbic acid is almost universally recognized. It is a water-soluble antioxidant and its concentration ranges from 30 to $100 \mu \mathrm{M}(0.54$ to $1.82 \mathrm{mg} / \mathrm{dL})$ in plasma. ${ }^{2}$ L-Ascorbic acid has a great reducing potential and reacts with many reactive oxygen and nitrogen species in vitro. In addition to food industry. L-ascorbic acid is extensively used in a number of cosmetic product claiming to protect the skin from environmental damages and photoaging ${ }^{3-5}$ In particular. L-ascorbic acid interferes with pigment production at various oxidative steps of melanin synthesis. for example 5.6-dihy'droxyindole oxidation. ${ }^{6} \mathrm{~L}$ Ascorbic acid has a reducing effect on o-quinones and oxidized melanin and it can alter melanin from jet black to light tan. However. one disadvantage of L-ascorbic acid is its chemical instability in aqueous solution where it becomes quickly oxidized and denatured. To overcome this problem. various stable derivatives of L-ascorbic acid have been extensively studied. Among them. several derivatives such as di- or tetraester compounds and magnesium L-ascorby 1-2phosphate are being used in cosmetic products. ${ }^{7}$

Recently. in a continuation of our study on the development of stable derivatives of L-ascorbic acid. we have had much interest in 3-aminopropane phosphoric acid because it was reported to stimulate collagen production in cultured human fibroblasts. ${ }^{8}$ Furthermore. it is very compatible with
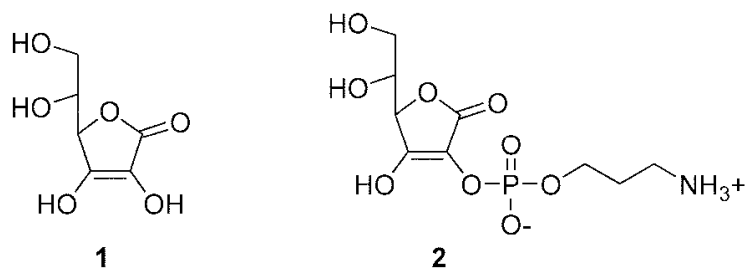

Figure 1. Structure of L-Ascorbic acid 1 and 2-O-[(3-aminopropyl)phosphinooxy]-L-ascorbic acid 2 skin and 3-aminopropane phosphoric acid is utilized as an active ingredient in cosmetic products. Based on these results. we prepared 2-O-[(3-aminopropyl)phosphinooxy]L-ascorbic acid (LAAP, 2) and evaluated the chenical stability and the depigmenting effects of LAAP on melanin sy'nthesis in normal human melanocytes compared with Lascorbic acid.

\section{Results and Discussion}

We synthesized 2-O-[(3-aminopropyl)phosphinooxy]-Lascorbic acid (LAAP. 2) by the reaction of 5,6-isopropylidene-L-ascorbic acid (†) and 2-chloro-[1.3.2]oxazaphosphinane 2-oxide (3) in the presence of triethylamine in dichloromethane. followed by hydrolysis in acidic condition (Scheme 1).

2-Chlorotetrahydro-2H-1.3,2-oxazaphosphorine 2-oxide (3) was obtained from the reaction of 3-aminopropan-1-ol and phosphonus oxychloride in the presence of triethylamine
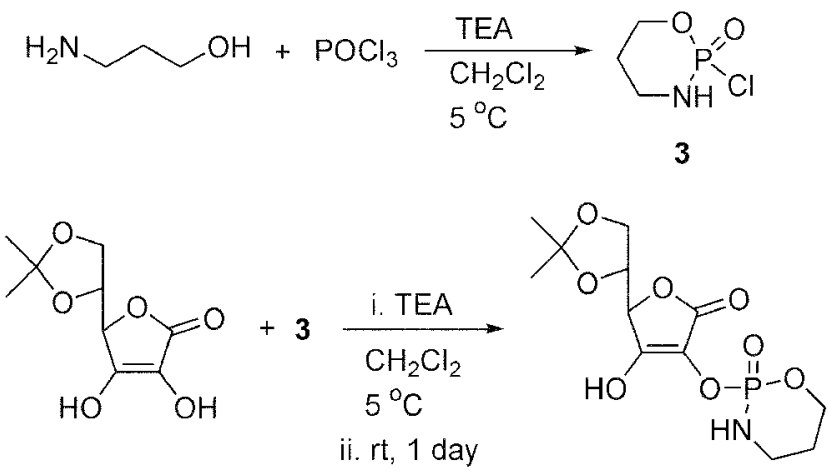

5

$$
\mid \begin{aligned}
& \mathrm{H}_{3} \mathrm{O}^{+} \\
& 50^{\circ} \mathrm{C}, 3 \mathrm{~h}
\end{aligned}
$$

Scheme 1. Synthesis of 2-O-[(3-aminopropyl)phosphinooxy]-Lascorbic acid. 
in organic solvent in good yield ( $91 \%$ ) and it can be used as a powerful precursor of 3-aminopropane phosphoric acid. In the previous study. by introducing 3-aminopropane phosphoric acid to unstable compound. we reported the development of the stable derivatives of kojic acid and tocopherol. 5-[(3-aminopropyl)phosphinooxy]-2-(hydroxymethyl)- $4 H$-pyran-4-one and 3-aminopropyl-DL- $\alpha$-tocopherylphosphate. ${ }^{5.10}$ The phosphorylation reaction of 4 with 2-chlorotetrahydro-2H-1.3.2-oxazaphosphorine P-oxide (3) can occur on both $2-\mathrm{OH}$ and/or $3-\mathrm{OH}$ of compound 4 . Generally: it is known that phosphorylation of L-ascorbic acid occurs on 2-OH in the aqueous reaction above $\mathrm{pH} 10$. while on $3-\mathrm{OH}$ in the presence of organic base in organic solvent. ${ }^{11.12}$ On the contrary; it was reported that the product from phosphorylation on $3-\mathrm{OH}$ of $\mathrm{L}$-ascorbic acid was conversed to more stable $2-\mathrm{OH}$ phosphorylated product in acidic aqueous condition. '" In our study' only one spot was detected on the TLC analysis of hydrolysis reaction mixture of compound 5 which was prepared by the reaction of 4 and 3 in the presence of triethylamine in dichloromethane. To determine whether phosphorylation occurred on $2-\mathrm{OH}$ or 3$\mathrm{OH}$ of L-ascorbic acid. some experiments were performed. $\mathrm{L}$-ascorbic acid displays two acidic protons of $\mathrm{pK}_{a}$ value 4.25 and 11.79 for the $3-\mathrm{OH}$ and $2-\mathrm{OH}$, respectively.!' The $\mathrm{pH}$ value of LAAP ( $1 \%$ aqueous solution) was 2 . It is known that sulfation or phosphorylation of $2-\mathrm{OH}$ enhances the acidity of 3-OH group of L-ascorbic acid by about 1 unit to $\mathrm{pK}_{\text {. }}$. while the acidity of $2-\mathrm{OH}$ group shows similar value as carbonic acid as a result of phosphorylation of 3-OH. From this result. we supposed that phosphorylation of compound 4 had occurred on 2-OH group. When compound 4 was reacted with compound 3 in the presence of 1 or 2 equivalent amount of triethylamine two new spots were detected on $\mathrm{TLC}\left(\mathrm{R}_{\mathrm{f}}=0.62 .0 .34 \mathrm{CHCl}_{3} / \mathrm{EtOH} / \mathrm{AcOH}=80 / 15 / 5\right)$. When 1 equivalent of trietlyy lamine was used. the upper spot $\left(R_{\mathrm{f}}=\right.$ 0.62 ) appeared predominantly. On the contrary when 2 equivalent was used the lower spot was major. When 1 equivalent was used. thereafter followed by addition of one more equivalent of triethylamine the lower spot became intense and the upper spot disappeared gradually. The $3-\mathrm{OH}$ group would participate in the reaction with compound 3 earlier than $2-\mathrm{OH}$ because the former is more acidic than the latter. From these results. we were sure the upper spot was corresponding to the 3-O-phosphate compound and the lower was 2-O-phosphate compound. In conclusion. when 2 equivalent amount of triethylamine was used in the phosphorylation of compound 4 with 3. 2-O-phosphate compound $\mathbf{5}$ was produced mainly. The final product $\mathbf{2}$ was prepared from deprotection of isopropylene group and hy'drolysis of P-N bond. According to our experiment using NMR tube the hydrolysis of P-N bond proceeded first. followed by deprotection of isopropylene group. Therefore. we obtained the product 2 by one step from the reaction in aqueous solution for $3 \mathrm{~h}$ at $50^{\circ} \mathrm{C}$.

The stability of LAAP and L-ascorbic acid was investigated by storing their aqueous solutions $(50 \mu \mathrm{M} . \mathrm{pH} 7)$ at 50 ${ }^{\circ} \mathrm{C}$ and analyzing each content at constant intervals at 259

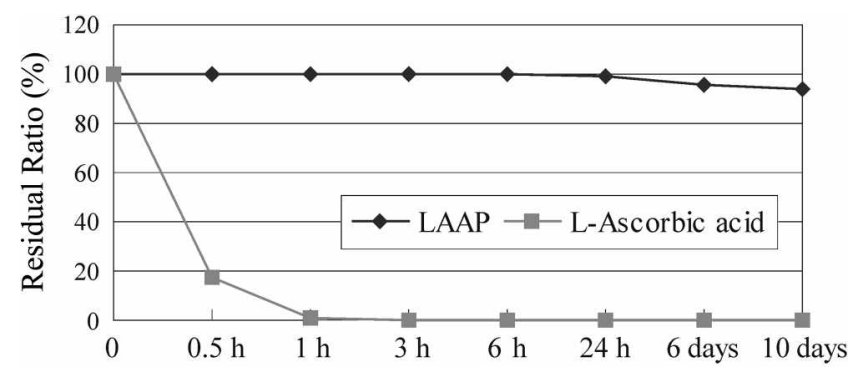

Figure 2. Stability of L-Ascorbic acid and 2-O-[(3-aminopropyl)phosphinooxy]-L-ascorbic acid in aqueous solution (pH 7) at 50 $\mathrm{c}$

$\mathrm{nm}$ for L-ascorbic acid-3-aminopropane phosphoric acid and at $266 \mathrm{~nm}$ for L-ascorbic acid by UV spectrophotometer (Hewlett Packard 8453 UV/VIS Spectrophotometer). Residual ratio was shown in Table 2 . According to our results. Lascorbic acid was decomposed completely within about 1 hour. while $93 \%$ of LAAP remained even after 10 days. Therefore. LAAP is much more stable in the neutral aqueous solution.

We investigated the depigmenting activity of L-ascorbic acid and LAAP in nonnal human melanocytes. Noe-melanin Synthesis was measured by the rate of incorporation of L-[3$\left.{ }^{14} \mathrm{C}\right] 3$.4-dihydroxy phenylalanine into newly synthesized melanins ${ }^{13}$ during the last $48-96 \mathrm{~h}$ of melanocyte treatment as described previously. ${ }^{14}$ This assay measures the complete reaction sequence of melanin biosynthesis and reflects the melanogenic activity of tyrosinase. tyrosinase-related proteins I and II. and inhibitory factors involved in this process. Inhibition effects of neo-melanin synthesis in normal human melanocyte treated with LAAP and L-ascorbic acid was shown in Table 1. According to the results. L-ascorbic acid decreased the melanin content of melanocytes to $33.8 \%$ and $78.2 \%$ of control at $2 \mathrm{mM}$ and $0.5 \mathrm{mM}$. respectively. On the contrary. LAAP decreased the melanin content of melanocytes to $49.1 \%$ and $88.4 \%$ of control at $2 \mathrm{mM}$ and $0.5 \mathrm{mM}$. respectively. Though the activity of LAAP was a little lower than L-ascorbic acid. 2-O-[(3-aminopropyl)phosphinooxy]$\mathrm{L}$-ascorbic acid also showed significant depigmenting effect. Furthermore. considering chemical instability of $\mathrm{L}$-ascorbic acid. 2-O-[(3-aminopropyl)phosphinooxy]-L-ascorbic acid is a much better whitening agent.

Table 1. Effects of LAAP and L-Ascorbic acid on Melanirn production of Normal Human Melanocyte

\begin{tabular}{ccc}
\hline Compound & $\begin{array}{c}\text { Concentration } \\
(\mathrm{mM})\end{array}$ & $\begin{array}{c}\text { Melanin Production } \\
\text { (\% of control) }\end{array}$ \\
\hline LAAP & 0.5 & $88.4 \pm 5.7^{\circ}$ \\
L-Ascorbic acid & 2 & $49.1 \pm 3.5^{\circ}$ \\
& 0.5 & $78.2 \pm 4.9^{\circ}$ \\
\hline
\end{tabular}

"Each ralue represents the mean $=$ S.D. of three experiments. Test materials were treated for 48 hours. An asterisk indicates values significantly different from the control group as determined by the twotailed $t$-test. ${ }^{*} \mathrm{p}<0.05$. 


\section{Experimental Section}

All melting points were determined on a Fisher Johns melting point apparatus and were uncorrected. ${ }^{1} \mathrm{H}$ and ${ }^{13} \mathrm{C}$ NMR spectra were recorded on a Varian GEMINI-300 BB $(300 \mathrm{MHz}$ ) spectrometer (with tetramethylsilane as an internal standard). Infrared (IR) absorption spectra were recorded on a JASCO IR-810. 5,6-Isopropyylidene-L-ascorbic acid was purchased from Aldrich Chemical Com. (Missouri. USA). Phosphons oxychloride and 3-aminopropan-1-ol were from Acros Organics. N. V. (Geel. Belgium). Solvents were laboratory grade or better.

2-Chloro-[1,3,2]oxazaphosphinane 2-oxide (3). To a solution of 3-amino-1-propanol (2.95 g. $39.3 \mathrm{mmol})$ and triethy lamine $(7.40 \mathrm{~g} .73 .1 \mathrm{mmol})$ in dichloromethane $(20$ $\mathrm{mL})$. a solution of phosphorus oxychloride $(5.69 \mathrm{~g} .37 .1$ mmol) was added dropwise at $5^{\circ} \mathrm{C}$ for $2 \mathrm{~h}$. After filtration to remove triethylamine hydrochloride salt. the filtrate was dried over $\mathrm{MgSO}_{4}$ followed by filtration and concentration in vacuo. The residue was precipitated by addition of toluene to give 2-chloro-[1.3.2]oxazaphosphinane 2-oxide 4 (5.30 g. $91 \%$ ) as a white solid. mp 79-82 ${ }^{\circ} \mathrm{C}: \mathrm{IR}(\mathrm{KBr}) 3254,1477$. 1274. 1092. 1036. $996 \mathrm{~cm}^{-1}:{ }^{1} \mathrm{H}$ NMR (300 MHz. $\left.\mathrm{CDCl}_{3}\right) \delta$ $1.61-1.80(\mathrm{~m} .1 \mathrm{H}) .2 .00-2.20(\mathrm{~m} .1 \mathrm{H}) .3 .20-3.42(\mathrm{~m} .2 \mathrm{H})$. $4.30-4.55(\mathrm{~m} .2 \mathrm{H}), 4.90$ (br. $1 \mathrm{H}) .{ }^{13} \mathrm{C}$ NMR $(300 \mathrm{MHz}$. $\left.\mathrm{CDCl}_{3}\right) \delta 25.78,25.85,42.05,71.69 .71 .81$

2-0-[(3-Aminopropyl)phosphinooxy]-L-ascorbic acid (LAAP, 2). To a suspension of 5,6-isopropylidene-Lascorbic acid $(10.0 \mathrm{~g} .46 .0 \mathrm{mmol})$ and triethylamine $(9.36 \mathrm{~g}$. $92.6 \mathrm{mmol})$ in dichloromethane $(20 \mathrm{~mL})$. 2-chloro-[1.3.2]oxazaphosphinane 2-oxide $(8.60 \mathrm{~g} .55 .0 \mathrm{mmol})$ in dichloromethane $(20 \mathrm{~mL})$ was added dropwise at $5^{\circ} \mathrm{C}$ for $1 \mathrm{~h}$. After the addition. the reaction mixture was further stirred at room temperature for 1 day. The mixture was washed with an aqueous phosphoric acid solution. then the organic layer was separated and dried over anhydrous sodium sulfate followed by decoloration with activated charcoal. The solution was filtered and concentrated under reduced pressure and used in the following hydrolysis reaction without further purification. The residue was dissolved in $30 \mathrm{~mL}$ of water and stirred at $50^{\circ} \mathrm{C}$ for $3 \mathrm{~h}$. Then. $150 \mathrm{~mL}$ of isopropanol was added to the solution to precipitate LAAP as a white solid. The product was filtered dried in vacho $(6.0 \mathrm{~g} .41 \%) . \mathrm{mp} 176-180^{\circ} \mathrm{C}$ : IR (KBr) $3500-2700\left(\mathrm{OH}, \mathrm{NH}_{3}^{+}\right) .1747(\mathrm{CO}) .1141 \mathrm{~cm}^{-1}$ (PO):
${ }^{1} \mathrm{H}$ NMR $\left(300 \mathrm{MHz}, \mathrm{D}_{2} \mathrm{O}\right) \delta: 1.90$ (q. $\left.J=6.3 \mathrm{~Hz}, 2 \mathrm{H}\right) .3 .05$ (t. $J=7.2 \mathrm{~Hz} .2 \mathrm{H}), 3.62(\mathrm{~d} . J=6.9 \mathrm{~Hz}, 2 \mathrm{H}) .3 .92-4.09(\mathrm{~m}, 3$ H) 4.42 (s. $1 \mathrm{H}):{ }^{13} \mathrm{C}$ NMR $\left(300 \mathrm{MHz}, \mathrm{D}_{2} \mathrm{O}\right) \delta 22.63 .22 .74$. $57.71,59.50 .59 .56,64.85,73.84,106.56,171.26,172.76$.

De novo melanin synthesis in normal human melanocytes. Neo-melanin synthesis was measured by the rate of incorporation of $\mathrm{L}-\left[3-{ }^{14} \mathrm{C}\right] 3$.4-dihydroxy phenylalanine into newly synthesized melanins ${ }^{13}$ during the last $48-96 \mathrm{~h}$ of melanocyte treatment as described previously.

Statistical Analysis. Data were presented as mean \pm S.D. from three independent experiments. Statistical comparison between different treatments was done by two-tailed $t$-test.

Acknowledgment. The authors are grateful to Amore Pacific R \& D Center for performing depignenting activity assay.

\section{References}

1. Davies. M. B.: Austinl. J.: Pautridge. D. A. Titamine C: Its Chentistry and Biochemisny. The Royal Society of Chemistry: Cambridge. U. K.. 1991.

2. Halliwell, B.; Gutteridge, J. M. C. Free Radicals in Biology and Medicine, 3rd Ed; Oxford University Press: Oxford. UT. K.. 1988.

3. Colven. R. M.: Pinnell. S. R. Clin. Dematol. 1996. 14. 227.

4. Hwang. S-H.: Han. Y-S.: Choy. T-H. Bull. Korean Chem. Soc. 2001. 22. 1019

5. Kong, B.: Ueom, J.: Kim, I.: Lim, D.: Kang, J.; Lee. K. Bull. Koram Chem. Soc. 2002. 23. 1773

6. Tomita. Y.: Hariu. A.: Mizuno. C.: Seiji. M. J. Invest. Demmatol. 1980. 75.379

7. Kameyama. K.: Sakai. C.: Kondoh. S. J. Am. Acad Dematol. 1996. $3+29$.

8. Lee. O. S.; Byon. Y. H.: Lee, B. S.; Hong. J. E.; Ko, J. S.: Cho. Y. K; Lee, H. LS Patent 5723645. 1998.

9. Kim. D. H.: Hwang. T. S.: Baek. H. S.: Kim. K.-T.: Lee. B. G.: Chang. I. S.: Kang. H. H.: Lee. O. S. Chem. Pham. Bull. 2003. 51.113.

10. Kim. K.-J; Kim, D. H.; Hong, J. E.; Chang, I. S.: Kang. H. H. J. Ant OIIChent Soc. 2001, 78, 441

11. Edwards, S. M.: Donnelly, T. A.; Sayre. R. M: Rheins, L. A. Photodematol. Photommunol. Photomed. 1994. 10. 111.

12. Jennow. I.: Blount. J.: Oliveto. E.: Perrota. A.: Rosen. P.: Toome. V. Tetrahedon 1979.35. 1483.

13. Hearing. V. J.: Ekel. T. M. Biochem. J. 1976. 157, 549.

14. Aberdam. E:; Romero, C.: Ortonne. J. P. J. Cell Sci. 1993, 106. 1015 . 